\title{
Effect of matrix particle size on EPS lightweight concrete properties
}

\author{
Duc Hoang Minh and Ly Le Phuong* \\ Vietnam Institute for Building Science and Technology, Vietnam
}

\begin{abstract}
Expanded polystyrene lightweight concrete is a composite which can be made by adding expanded polystyrene aggregate in normalweight concrete (as matrix). The research was focused on the effect of properties and volume of the matrix on the properties of lightweight concrete. The results show that properties of structural polystyrene concrete, such as workability and compressive strength, depend on the aggregate size of the matrix. It also shows that decreasing aggregate size of the matrix is the effective way to increase workability and compressive strength of lightweight concrete. When the density of concretes decrease by $200 \mathrm{~kg} / \mathrm{m}^{3}$, slump values decrease by about 20 to $30 \mathrm{~mm}$ with lightweight concrete mixtures using maximum particle size of $0.63 \mathrm{~mm}$, while slump values decrease by about $40 \mathrm{~mm}$ with the mixtures using maximum particle size of $20 \mathrm{~mm}$. At the same density, the compressive strength of the structural polystyrenre concrete significantly decreased when the coarse aggregate diameter greater than $10 \mathrm{~mm}$. Therefore, coarse aggregates with diameter size are smaller than $10 \mathrm{~mm}$ was recommended to use for matrix. In the result, expanded polystyrene concrete with density from $1,400 \mathrm{~kg} / \mathrm{m}^{3}$ to $2,000 \mathrm{~kg} / \mathrm{m}^{3}$ and compressive strength more than 20 MPa for structural application was made.
\end{abstract}

\section{Introduction}

Lightweight concretes have been successfully used in the construction, thanks to its low density. To produce lightweight concrete, we can use several types of inorganic lightweight aggregates, like expanded clayd, agropolite, or organic lightweight aggregates like expanded polystyrene (EPS). When lightweight concrete base on inorganic lightweight aggregates has been widely used, lightweight concrete base on organic lightweight aggregates like EPS is now considered to be a new material in Vietnam. Polystyrene concrete, with density from about $500 \mathrm{~kg} / \mathrm{m}^{3}$ to $900 \mathrm{~kg} / \mathrm{m}^{3}$, is being used in non-structural applications, has been studied and applied in many projects. Polystyrene concrete also can be manufactured with higher density and strength to meet the requirements of concrete for structural application. However, until now the structural lightweight concrete using EPS aggregate is not specified in standard.

\footnotetext{
* Corresponding author: lephuongly.ibst@gmail.com
} 
Base on number of studies [1, 2], non-structural polystyrene concrete element have been carried out to produce no-structural element in factor, with density from about $500 \mathrm{~kg} / \mathrm{m}^{3}$ to $900 \mathrm{~kg} / \mathrm{m}^{3}$ and compessive from 2.5 MPa to 5.0 MPa. Moreover, polystyrene concrete also can be used to produce monolithic structures on construction site. This is a great advantage over autoclaved aerated concrete or foam concrete. Further, by varying the amount of EPS, the density of polystyrene concrete can be adjusted from $450 \mathrm{~kg} / \mathrm{m}^{3}$ to $2,000 \mathrm{~kg} / \mathrm{m}^{3}$ [3, 4]. Both expanded polystyrene beads and polystyrene waste can be used as aggregates [6]. Using mineral admixtures, such as fly ash [5, 6, 7], silicafume [4], rice husk ash [8], nano silicafume [9], improved durability, performance and reduced porosity of polystyrene concrete. But, it also effects on workability of mixture. So, studies $[8,10]$ used water reducing admixtures in mix designs.

The previous studies $[4,10,11]$ indicated that EPS particle size affected properties of polystyrene concrete, particularly compressive strength. EPS with diameter from $1 \mathrm{~mm}$ to $2.5 \mathrm{~mm}$ is less likely to affect the compressive strength of concrete [10]. Thus, using this EPS's particle size does not significantly affect compressive strength of polystyrene concrete with equal density from $1,400 \mathrm{~kg} / \mathrm{m}^{3}$ to $2,000 \mathrm{~kg} / \mathrm{m}^{3}$.

The present of coast aggregate in matrix was studied in [4] and the result showed that compressive strength of polystyrene concrete improved when matrix with coast aggregate was used. But, all effect of matrix and normal aggregate was not disclose.

EPS beads have a spherical shape with an internal cellular structure and a smooth, nonabsorbent surface. Thus, unlike other lightweight aggregates such as expanded clayd or expanded perlite, which are lightweight aggregates with high water absoption, the presence of EPS in concrete does not alter the amount of free water, its mind the proportion water on cement of matrix does not change. EPS does not interact chemically with matrix but reduces the density of concrete. However, the presence of low elastic modulus EPS also has a significant effect on the physical, mechanical, deformative properties of concrete. Polystyrene concrete can be considered as a composite material in which EPS is evenly distributed in normal weight concrete as matrix. In particular, EPS is added to modify the matrix to reduce the density and also changing the other properties of the concrete mixture and concrete. So, the properties of polystyrene concrete can be classifed by the EPS properties, the concrete properties and the ratio of the two components.

EPS beads, with particle size of 1.5 to $5.0 \mathrm{~mm}$, is the same size as fine aggregate. In combination with normal aggregate, we have three types of structures.

When EPS particle size is larger than the maximum particle size of the aggregate in matrix, structures of polystyrene concrete is similar to structures of expanded clayd concrete which use expanded clayd coarse aggregate and normal fine aggregate. Therefore, it is possible to calculate the mortar excessive coefficient in lightweight concrete. Study [3] showed that mortar excessive coefficient has a significant effect on the properties of polystyrene concrete with volume less than $700 \mathrm{~kg} / \mathrm{m}^{3}$. However, with structural polystyrene concrete, having density from $1,400 \mathrm{~kg} / \mathrm{m}^{3}$ to $2,000 \mathrm{~kg} / \mathrm{m}^{3}$ and having maximum particle size of normal aggregate smaller than EPS particle size, the mortar excessive coefficient is high. Due to the compressive strength of the EPS aggregate is negligible, the matrix acts as a force frame. The workability and compressive strength depend on properties of matrix and the spacing between the EPS beads.

In the two orther types of structures, when EPS particle size is less than or equal to the maximum particle size of the aggregate in the matrix, we can use normal coarse aggregates in the matrix for structural polystyrene concrete, having density from $1,400 \mathrm{~kg} / \mathrm{m}^{3}$ to 2,000 $\mathrm{kg} / \mathrm{m}^{3}$. With a high volume percentage of matrix, high density of lightweight concrete mixture, space between EPS bead may be large enough for coarse aggregates. By reducing volume percentage of matrix, the presence of coarse aggregates may affect EPS distribution in concrete. The amount of cement mortar decreased, the distance between EPS aggregates 
decreased, the effect of aggregate size of matrix to the compressive strength of lightweight concrete increased. Thus, it can be seen that EPS is distributed evenly in cement mortar mix of matrix.

Nowaday in Vietnam polystyrene concrete is considered as an effective material due to the advantage compared to foam concrete in waterproofing ability and due to the advantage compared to the expanded clayd concrete in the available source materials. Widening the application of polystyrene concrete in construction in Vietnam in the next time can be achieved by developing the structural lightweight concrete with density up to $2,000 \mathrm{~kg} / \mathrm{m}^{3}$, compressive strength over $20 \mathrm{MPa}$ that is suitable for structural application. This paper presents the research carried out at the Institute of Concrete Technology - Viet Nam Institute for Building Science and Techonology on the effect of the particle size of the aggregate in matrix to workability and compressive strength of polystyrene concrete that has unit weight from $1,400 \mathrm{~kg} / \mathrm{m}^{3}$ to $2,000 \mathrm{~kg} / \mathrm{m}^{3}$.

\section{Materials and testing plant}

\subsection{Materials and testing methods}

In this study, the properties of the materials and the concrete mixture are determined according to the standard methods specified in the national standard.

Particularly with EPS, due to the density is much smaller than the density of normal aggregate, this study determined the density of EPS by calculation, by determining bulk density and voids of EPS aggregate, according to the method used in the study [3]. The void between EPS beads is determined by the ratio of water volume added to the graduated tube to the pre-packed EPS and kept constant. EPS particle size $1.5 \div 2.5 \mathrm{~mm}$ with particle density is $19.7 \mathrm{~kg} / \mathrm{m}^{3}$, bulk density is $11.1 \mathrm{~kg} / \mathrm{m}^{3}$ was used.

Poocland cement of But Son plant with compressive strength at 28 days of $44.3 \mathrm{MPa}$, density of $3.05 \mathrm{~g} / \mathrm{cm}^{3}$, surface specific area of $3,410 \mathrm{~cm}^{2} / \mathrm{g}$. Silicafume D920 has a specific gravity of $2.2 \mathrm{~g} / \mathrm{cm}^{3}$. In this investigation super plasticizer (SP) base on polycacbosylalete was used. SP was able to reduce water content by $25-30 \%$, with a density of $1.05 \pm 0.02$ $\mathrm{g} / \mathrm{ml}$. To adjust the viscosity of the concrete mixtures, we used powdered hydroxypropyl methylcellulose based additives (VM), having a $\mathrm{pH}$ value of $4-8$, a viscosity of 35,000 $47,000 \mathrm{mPa} . \mathrm{s}\left(2 \%\right.$ solution $\left.20^{\circ} \mathrm{C}\right)$.

Table 1. The properties of normal aggregates

\begin{tabular}{|c|l|c|r|c|c|c|c|}
\hline No & \multicolumn{1}{|c|}{ Testing items } & Unit & C1 & C2 & C3 & D1 & D2 \\
\hline 1 & Apparent specific gravity & $\mathrm{g} / \mathrm{cm}^{3}$ & 2.66 & 2.65 & 2.65 & 2.85 & 2.85 \\
\hline 2 & Bulk specific gravity (SSD) & $\mathrm{g} / \mathrm{cm}^{3}$ & 2.64 & 2.64 & 2.64 & 2.84 & 2.84 \\
\hline 3 & Bulk specific gravity (Dried) & $\mathrm{g} / \mathrm{cm}^{3}$ & 2.62 & 2.63 & 2.63 & 2.8 & 2.8 \\
\hline 4 & Water Absorption & $\%$ & 0.4 & 0.2 & 0.2 & 0.5 & 0.5 \\
\hline 5 & Bulk density & $\mathrm{kg} / \mathrm{m}^{3}$ & 1,449 & 1,445 & 1,445 & 1,394 & 1,408 \\
\hline 6 & Voids & $\%$ & 45 & 45 & 45 & 50 & 50 \\
\hline 7 & Content of dust, mud and clay & $\%$ & 0.7 & 0.5 & 0.5 & - & - \\
\hline 8 & Maximum particle size & $\mathrm{mm}$ & 0.63 & 1.25 & 5.00 & 10.00 & 20.00 \\
\hline
\end{tabular}

The corase aggregate used in the study is crushed carbonate, having the maximum particle size is $10 \mathrm{~mm}$ (D1) and $20 \mathrm{~mm}$ (D2). Fine aggregates with the maximum particle 
size of $0.63 \mathrm{~mm}(\mathrm{C} 1), 1.25 \mathrm{~mm}(\mathrm{C} 2), 5.00 \mathrm{~mm}(\mathrm{C} 3)$ were used. The properties of the normal aggregates are shown in Table 1.

\subsection{Testing plant}

Structural polystyrenre concretes is made by adding a certain amount of EPS aggregate that calculated on the basic of the density concrete mixture and the properties of material, matrix. To investigate the effect of matrix and EPS on the properties of structural polystyrenre concretes, we have used matrix concrete mixer with different properties and materials (Table 2). Based on these concrete mixes, the polystyrene concrete is made by adding EPS to the concrete mixture to achieve a density in the predetermined range of

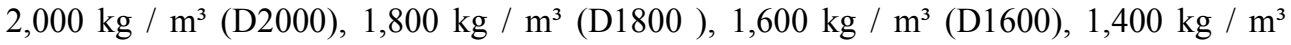
(D1400).

Table 2. Details of matrix concrete mixes.

\begin{tabular}{|c|c|c|c|c|c|c|c|c|c|c|c|c|}
\hline \multirow[b]{2}{*}{ SInumber } & \multirow[b]{2}{*}{$\begin{array}{c}\text { Type of } \\
\text { aggregates }\end{array}$} & \multirow[b]{2}{*}{$\begin{array}{c}\text { Dmax, } \\
\mathbf{m m}\end{array}$} & \multicolumn{7}{|c|}{ Details of matrix concrete mixes } & \multicolumn{3}{|c|}{ Properties } \\
\hline & & & $\begin{array}{c}\text { Cement, } \\
\mathbf{k g} / \mathrm{m}^{3}\end{array}$ & $\begin{array}{l}\text { Water, } \\
\mathrm{kg} / \mathrm{m}^{3}\end{array}$ & $\begin{array}{l}\text { Sand, } \\
\mathrm{kg} / \mathbf{m}^{3}\end{array}$ & \begin{tabular}{|c|} 
Normal \\
aggregates \\
$\mathbf{~ k g / \mathbf { m } ^ { 3 }}$ \\
\end{tabular} & $\underset{\mathrm{kg} / \mathrm{m}^{3}}{\mathrm{SF}}$ & \begin{tabular}{|}
$\mathrm{SP}$ \\
$\mathrm{kg} / \mathbf{m}^{3}$
\end{tabular} & $\begin{array}{c}\mathrm{VM}, \\
\mathrm{kg} / \mathrm{m}^{3}\end{array}$ & $\begin{array}{c}\text { Density, } \\
\mathbf{k g} / \mathbf{m}^{3}\end{array}$ & $\begin{array}{c}\text { Flow, } \\
\text { mm }\end{array}$ & $\begin{array}{l}\mathbf{R}^{*} \\
\mathbf{M P a}\end{array}$ \\
\hline M0.63.80.21 & $\mathrm{C} 1$ & 0.63 & 808 & 314 & 990 & 0 & 80.80 & 8.48 & 1.21 & 2,160 & 22.0 & 82.01 \\
\hline M0.63.80.18 & $\mathrm{C} 1$ & 0.63 & 809 & 315 & 990 & 0 & 80.88 & 6.28 & 1.21 & 2,160 & 18.0 & 80.00 \\
\hline M0.63.80.14 & $\mathrm{C} 1$ & 0.63 & 809 & 315 & 990 & 0 & 80.92 & 5.10 & 1.21 & 2,160 & 14.0 & 80.44 \\
\hline M1.25.80.21 & $\mathrm{C} 2$ & 1.25 & 793 & 309 & 970 & 0 & 79.34 & 8.33 & 1.19 & 2,120 & 21.0 & 82.51 \\
\hline M1.25.80.18 & $\mathrm{C} 2$ & 1.25 & 794 & 309 & 970 & 0 & 79.41 & 6.17 & 1.19 & 2,150 & 18.0 & 82.07 \\
\hline M100.80.21 & $\mathrm{D} 1, \mathrm{C} 3$ & 10.00 & 595 & 231 & 730 & 660 & 59.47 & 6.24 & \begin{tabular}{|l|}
0.89 \\
\end{tabular} & 2,280 & 20.5 & 78.18 \\
\hline M100.80.18 & $\mathrm{D} 1, \mathrm{C} 3$ & 10.00 & 595 & 231 & 730 & 660 & 59.51 & 4.75 & 0.89 & 2,250 & 18.0 & 76.46 \\
\hline M100.80.14 & D1, C3 & 10.00 & 595 & 232 & 730 & 660 & 59.53 & 3.81 & \begin{tabular}{|l|}
0.89 \\
\end{tabular} & 2,260 & 14.0 & 75.39 \\
\hline M200.80.21 & $\mathrm{D} 2, \mathrm{C} 3$ & 20.00 & 610 & 237 & 750 & 680 & 61.04 & 6.41 & 0.92 & 2,300 & 20.5 & 81.11 \\
\hline M200.80.18 & $\mathrm{D} 2, \mathrm{C} 3$ & 20.00 & 593 & 231 & 720 & 660 & 59.27 & 3.80 & 0.89 & 2,270 & 18.0 & 82.44 \\
\hline M200.80.14 & $\mathrm{D} 2, \mathrm{C} 3$ & 20.00 & 595 & 232 & 730 & 660 & 59.53 & 3.81 & 0.89 & 2,260 & 14.0 & 82.20 \\
\hline
\end{tabular}

\section{Test results and discussion}

\subsection{Workability}

To study the effect of matrix volume on the workability of concrete mixture, the matrix M0.63.80.21, M1.25.80.21, M100.80.21, M200.80.21 with four different particle size of aggregates were used. The matrix used the same amount of VM is $0.15 \%$ (of cement content by weight) and had the same workability. Effect of matrix percentage by volume on workability of concretes are shown in Fig. 1.

When EPS aggregate is added to lower the density of concrete, the workability of polystyrene concrete depends mainly on matrix percentage by volume. Decreasing the amount of volume matrix, the slump value decreases. The slump lose is raised with increasing particle size of matrix (Fig. 1). At the same density of $1,400 \mathrm{~kg} / \mathrm{m}^{3}$, the workability of the concrete mixtures base on matrix M0.63.80.21 remains at $120 \mathrm{~mm}$ while the concrete mixtures using matrix M100.80.21 and M200.80.21 are only $20 \mathrm{~mm}$ to $60 \mathrm{~mm}$. 
Thus, with the same value of density of lightweight concrete and the same workability of matrix, the workability of the polystyrenre concretes mixture decrease when the maximum particle size of the matrix increase.

Clarifing the effect of workability and maximum particle size of matrix to the workability of the concrete, experiments were performed with polystyrenre concretes mixtures density of $1,600 \mathrm{~kg} / \mathrm{m}^{3}$ based on matrix M0.63.80.21, M1.25.80.21, M100.80.21, M200.80.21 in Table 2. The performance of matrix is adjusted by changing the percentage of super plasticizer admixture on cement.

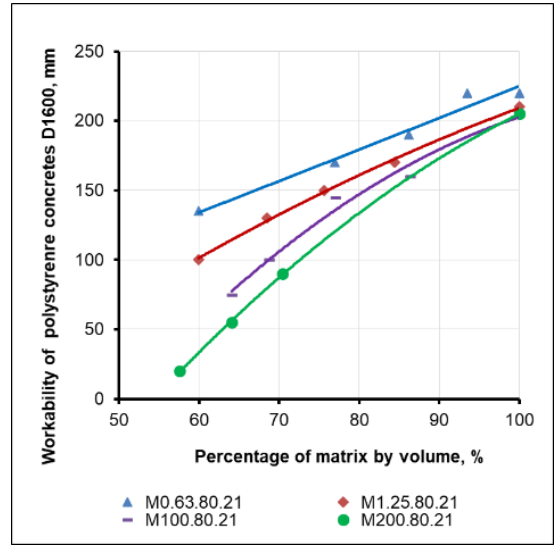

Fig. 1 Effect of density on workability of concretes

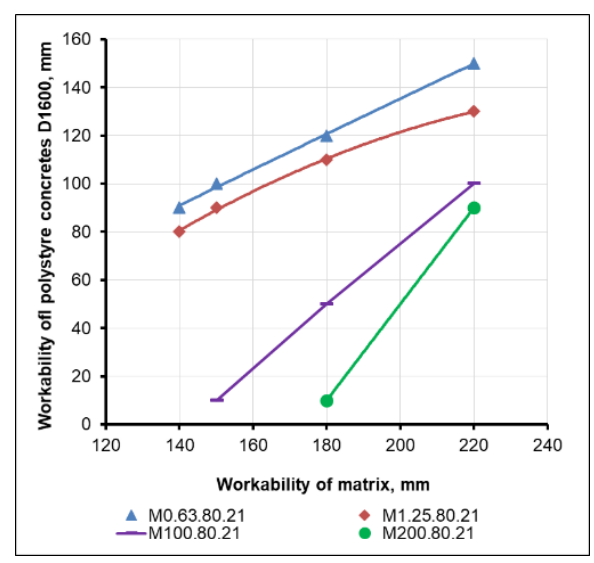

Fig. 2 Effect of matrix's workability on workability of structural polystyrenre concretes

The results (Fig. 2) show that the workability of the concrete mixture, base on the matrix using coarse aggregates D1 and D2, decreases rapidly as the density of concrete decreases. Specifically, workability of the matrix using aggregate D2 is $180 \mathrm{~mm}$, the workability of the polystyrenre concretes blend was $10 \mathrm{~mm}$ at D1600, while the corresponding value for the aggregate D1 is $50 \mathrm{~mm}$, the aggregate $\mathrm{C} 1$ is $140 \mathrm{~mm}$. Thus, the smaller the particle size in matrix, the less the degree of workability.

Thus, adding EPS in to matrix reduces the amount cement paste in the polystyrenre concretes mixture. The paste around the aggregate, fills the voids between the aggregates, and acts as a cushioning layer for the concrete mix. When using EPS to reduce density of concrete, the volume of cement paste in polystyrenre concretes is smaller than in matrix. The smaller density of polystyrenre concretes, the lower the volume of cement paste, reducing workability of the mixture.

To reseach the effect of matrix's workability on workability of lightweight concretes, the study used M200.80.21, M200.80.18, M200.80.14 (Table 2) using aggregates D2 with maximum particle size of $20 \mathrm{~mm}$ and M0.63.80.21, M0.63.80.18, M0.63.80.14 (Table 2) using aggregate $\mathrm{C} 1$ with maximum particle size of $0.63 \mathrm{~mm}$. Based on these data, the regression between the workability of the structural polystyrenre concretes mixture and the workability of the concretes was build.

Fig. 3, Fig. 4 shows the relationship between the workability of the polystyrenre concretes mixture and the workability of the matrix with structural polystyrenre concretes

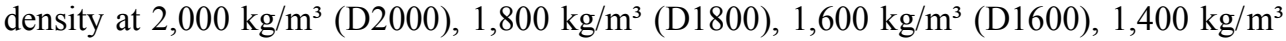
(D1400). When the workability of matrix down $40 \mathrm{~mm}$, the workability of lightweight concretes mixture also reduced by about $40 \mathrm{~mm}$. This shows the workability of polystyrenre concrete not only depends on percentage of matrix by volume but also depends on its properties. The concrete mixes used in this study have the same water content. Therefore, with the same density can be considered the aggregate of polystyrenre 
concretes is the same, the buffer layer is formed by the same paste. The different workability between the same density mixes are completely affected by the flexibility of the paste in the matrix.

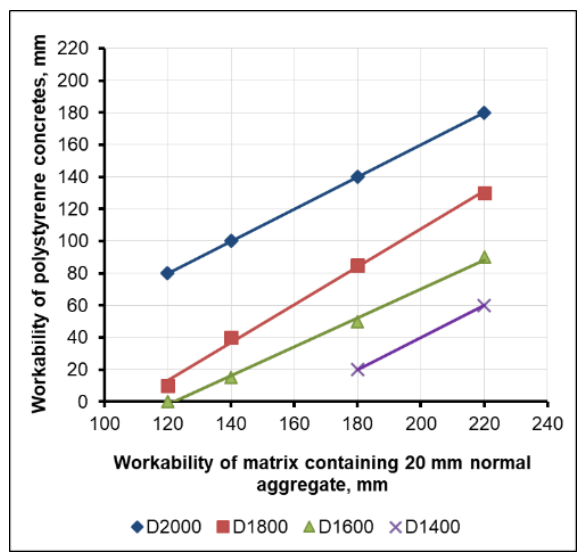

Fig. 3 Effect of matrix's workability on workability of concretes containing $20 \mathrm{~mm}$ normal aggregate

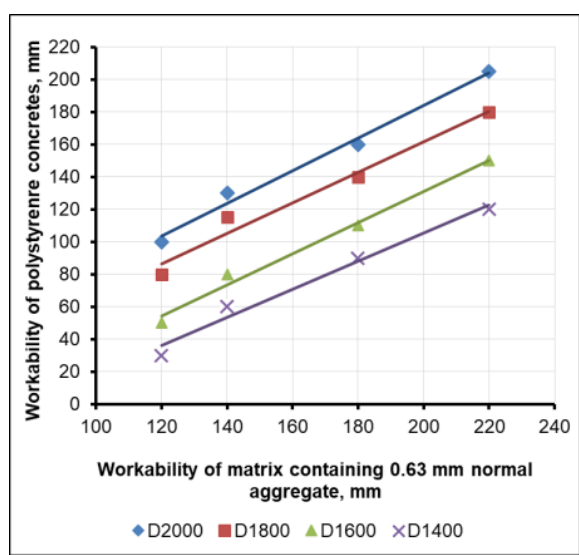

Fig. 4 Effect of matrix's workability on workability of concretes containing $0.63 \mathrm{~mm}$ normal aggregate

The results also indicated wide variation in the degree of decreasement in workability when using matrix with the diffirence maximum particle size. Concrete mixtures with aggregate $\mathrm{C}$, having the maximum particle size of $0.63 \mathrm{~mm}$, slump values decrease by about 20 to $30 \mathrm{~mm}$ when the density of concretes decrease by $200 \mathrm{~kg} / \mathrm{m}^{3}$. Concrete using aggregate D2 tends to reduce its workability faster, about $40 \mathrm{~mm}$ when density decreased by $200 \mathrm{~kg} / \mathrm{m}^{3}$. This is also shown in Fig. 1 . Thus, at the same workability of the matrix, at the same density of polystyrenre concretes, the aggregate size increased, the worability of polystyrenre concretes decreased and the rate loss increased.

\subsection{Compressive strength}

The volume of matrix decreases with decrease in density of polystyrene concrete and hence results in a decrease in compressive strength of the lightweight concrete, but decreasement depends on some factors. Comparing the strength results of mixes M1.25.80.21, M200.80.21 (Table 2), it is clear that the compressive strength of polystyrene concrete was influenced primarily by the density of concrete and the percentage of matrix by volume (Fig. 4, Fig. 5). The attenuation of strength followed the curve with the change of magnitude when the density is less than $1,600 \mathrm{~kg} / \mathrm{m}^{3}$. The decreasement in compressive strength at the M200.80.21 is more than the M1.25.80.21.

The study used the matrixes M0.63.80.21, M1.25.80.21, M100.80.21, M200.80.21, with particle size is $0.63 \mathrm{~mm}, 0.125 \mathrm{~mm}, 10 \mathrm{~mm}, 20 \mathrm{~mm}$. Concrete mixtures, after add the predetermined EPS, are determined the workability, density and compressive strength. Based on these data, the study establishes a regression equation which shows the relationship between the maximum particle size in the matrix and the compressive strength of the polystyrene structural concrete. The results is presented in Fig. 7 with density of

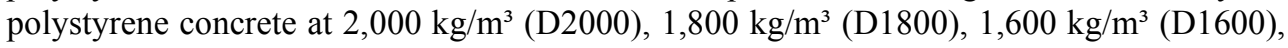
$1,400 \mathrm{~kg} / \mathrm{m}^{3}$ (D1400). 
The results is presented in Fig. 5 shows that the compressive strength of concrete decreases as the maximum aggregate diameter in the matrix increases. When adding EPS in to the matrixs M100.80.21 or M200.80.21, EPS are evenly distributed in the grout between coarse aggregate particles. When EPS volume is enough to allow paste to cover the surface of aggregate, including coarse aggregates, sand and EPS, the structure of the polystyrene concrete significantly changes exhibited in stone structure binder becomes discontinuous. Then, the compressive strength of the polystyrene concrete is significantly reduced. With the matrix M0.63.80.21, M1.25.80.21 (Table 2), the compressive strength of polystyrene concrete remains well at low density.

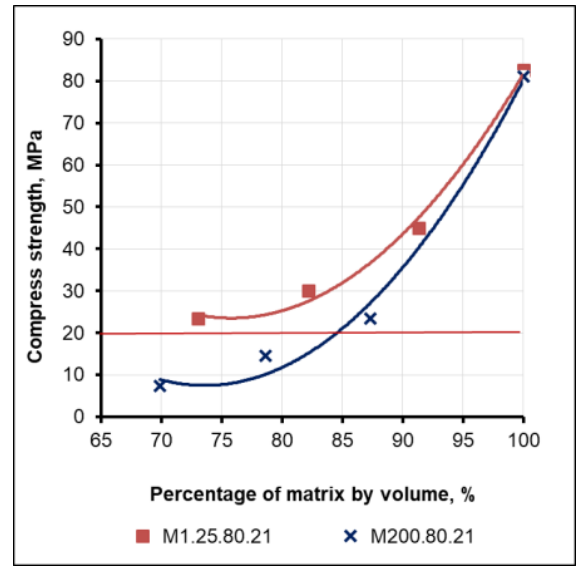

Fig. 4 Effect of matrix particle size on strength of structural polystyrenre concretes.

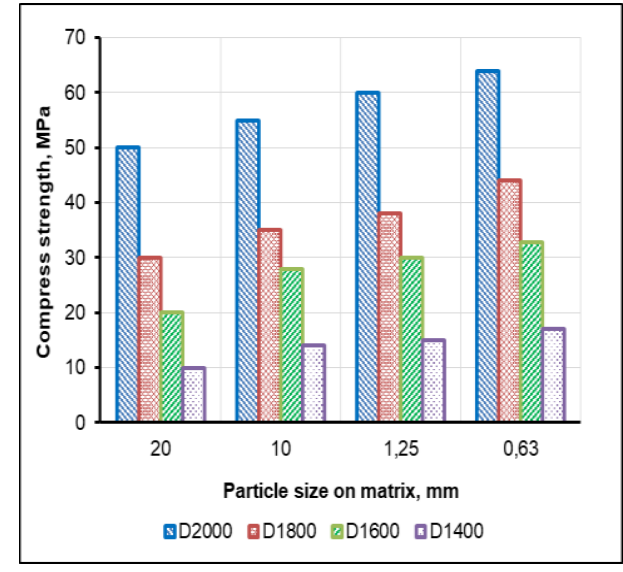

Fig. 5 Effect of matrix particle size on strength of structural polystyrenre concretes.

This is due to the greater amount of cement paste in the matrix than in lightweight concrete. The volume of the paste in the polystyrene concrete is smaller than in the matrix. The lower the ratio volume of matrix, the lower the volume of the paste. Due to the elasticity of EPS, the strength of the polystyrene concrete depends on the strength and structure of the concrete. By reducing the density, the thickness of this bonding region is significantly affected by the compressive strength of the polystyrene concrete.

Research progress in effect of aggregate diameter in matrix on the properties of lightweight concrete showed that at each density of polystyrene concrete, there is one particle size of normal aggregate so that the compressive strength of concrete reaches the maximum value.

\section{Conclusions}

Base on results of the study, the following conclusions can be made:

- When EPS aggregate is added to lower the density of concrete, the workability of polystyrene concrete depends mainly on matrix percentage by volume. Decreasing the amount of volume matrix, the slump value decreases. The slump lose is raised with increasing particle size of matrix. When the density of concretes decrease by $200 \mathrm{~kg} / \mathrm{m}^{3}$, slump values decrease by about 20 to $30 \mathrm{~mm}$ with lightweight concrete mixtures using maximum particle size of $0.63 \mathrm{~mm}$, while slump values decrease by about $40 \mathrm{~mm}$ with the mixtures using maximum particle size of $20 \mathrm{~mm}$.

- At the same workability and strength of matrix, the workability and strength of lightweight concretes mainly decreased as the aggregate size of matrix increased. The 
decreasement in strength base on matrix containing $20 \mathrm{~mm}$ coarse aggregate was more than the concretes base on matrix containing $1.25 \mathrm{~mm}$ fine aggregate.

- While keeping the workability and strength of the matrix constant, aggregate the size of the matrix decrease with the increase of lightweight concrete compressive strength. At the same density, the compressive strength of the structural polystyrenre concrete significantly decreased when the coarse aggregate diameter greater than $10 \mathrm{~mm}$. Therefore, coarse aggregates with diameter size are smaller than $10 \mathrm{~mm}$ was recommended to use for matrix.

\section{References}

1. D.J. Cook, Expanded polystyrene beads as lightweight aggregates for concrete, Precast Concrete 4 (1973)

2. B. Saaba, R.S. Ravindrarajah, Engineering properties of lightweight concrete containing crushed expanded polystyrene waste, Proc. Materials Research Society 1997 Fall Meeting, Boston (1997)

3. HM. Duc, Nghiên cứu chế tạo bê tông nhẹ cách nhiệt kết cấu sử dụng hạt polystyrene phồng nở. Tạp chí KHCN Xây dựng 4 (2017)

4. K.G. Babu, and D.S. Babu, Behaviour of lightweight expanded polystyrene concrete containing silica fume. Cement and Concrete Research (2003)

5. S.Babu, D., K. Ganesh Babu, and T.H. Wee, Properties of lightweight expanded polystyrene aggregate concretes containing fly ash. Cement and Concrete Research (2005)

6. B.A.Herki, J.M. Khatib, and E.M. Negim, Lightweight Concrete Made from Waste Polystyrene and Fly Ash. World Applied Sciences Journal 21 (9) (2013)

7. K.B.Babu, Performance of fly ash concretes containing lightweight EPS aggregates. Cement and Concrete Composites, Volume 26 (2004)

8. M.A. Ali Sadr Momtazi, Alebar Khodaparast Haggi, Hadi Rasmi Atigh, Durability of Lightweight Concrete Containing EPS In Salty Exposure Conditions. Second Intermational Conference on Sustainable Construction Material and Technologies (2010)

9. M. Fathi, A. Yousefipour, and E. Hematpoury Farokhy, Mechanical and physical properties of expanded polystyrene structural concretes containing Micro-silica and Nano-silica. Vol. 136 (2017)

10. K. Miled, K. Sab, and R. Le Roy, Particle size effect on EPS lightweight concrete compressive strength: Experimental investigation and modelling. Mechanics of Materials (2007)

11. N. Liu and B. Chen, Experimental study of the influence of EPS particle size on the mechanical properties of EPS lightweight concrete. Construction and Building Materials (2014) 